\title{
PART 1. \\ METROPOLITAN ANDREY SHEPTYTSKY IN THE LIGHT OF THE DOCUMENTS
}

The first attempt to systematize and publish the pastoral letters of Metropolitan was made in 1965 by Anatol M. Bazylevych. The first volume included the works of A. Sheptytsky, covering the period from August 2, 1899 to September 7, 1901. The author rightfully noted that "in Ukraine, the works, letters, documents concerning the figure of Metropolitan Andrey Sheptytsky, his life and activities, were still not widespread, which is a significant barrier to the knowledge and understanding of this outstanding personality, his inviolable authority, his influence on the spiritual, socio-political, cultural development of the Ukrainian people"1. The collection includes "The Shepherd's First Word", "Our Program", "The Christian Family", "True Faith", "To My Beloved Hutsuls", "On the Edge of Two Ages", "The Great Commandment", "About the Church", "About dignity of priests", "To the Ukrainian intelligentsia", "About repentance", "About anniversary", "To Rusyns settled in Canada", In the preface to the second volume of A.M. Basylevych, M. Hrynchyshyn rightfully emphasized some of the difficulties that arose during the publication of Sheptytsky's works. "When in 1926, on the occasion of the 25th anniversary of the Metropolitan rule by Kyr Andrey Sheptytsky, bishop Botsyan was writing a literary review of Metropolitan's pastoral messages that had appeared by then, even then he could not obtain the texts of all the messages. And since then, the second quarter of the century and the World War II have passed"3.

Anatol M. Bazylevych in his fundamental work "Introduction to the Works of Metropolitan Andrey Sheptytsky" clearly outlined the main purpose of his work. "Not to create the archives as a main goal," writes the author, "for this it would be enough to collect the materials and arrange them properly, but the urge or right to make the works of the Metropolitan accessible to the widest circles, to the researchers on the one hand, and to the public on the other. The life of Metropolitan, admired by his contemporaries, is an example, which is not

1 Твори Слуги Божого Митрополита Андрея Шептицького. Пастирські листи. T. I. Репринтне видання. Львів: Монастир Монахів Студійського Уставу - Видавничий відділ «Свічадо», 1994. 282 с.

${ }^{2}$ Ibid. C. 1-266.

${ }^{3}$ Базилевич М. Анатоль. Введення у твори митрополита Андрея Шептицького. Праці Українського Богословського Наукового Товариства. Т. XV. Торонто, 1965. С. В-5. 
passing away, and that's why it shines on the present generations..." merit of A. Bazylevych lies not so much in the publication itself as in the attempt to group and organize the works of Metropolitan. The author acknowledges that the classification he proposes is somewhat conditional, since many of Sheptytsky's messages sometimes touch a dozen issues. It is worth agreeing with such considerations. We should add that the periodization of the works of Metropolitan proposed by the researcher has not lost its relevance today. Thus, A. Bazylevych grouped A. Sheptytsky's heritage into seven parts: «1) theological-pastoral and ascetic works; 2) constitutional letters and monastery statutes; 3 ) writings on the topic of Church unity (ecumenical views of A. Sheptytsky - Aut.); 4) writings about ceremonial cases; 5) historical works; 6) Metropolitan's views on art; 7) writings on social topics and other"5.

In chronological terms, A. Bazylevych divides the works of Metropolitan into three periods: "The first period from 1899 to 1914, that is, from the time of his accession to the episcopal throne in Stanislaviv until his removal to the depths of Russia in September 1914. The second period is a period from then until 1927, that is, until the Fifth Congress of Velehrad, in which Metropolitan participated, and to the writing of [the work - Aut.] "Eastern and Western Mentality" (1927). The third period dates from the end of the great speeches about union and conferences of Metropolitan, first of all in Western Europe, that is, from 1928 to 1944, that is, until the end of his life. In the work of Metropolitan, the most productive were the last and the first periods, except of 1903, when Metropolitan was ill and did not write» ${ }^{6}$. A. Bazylevych also paid attention to Sheptytsky's language and style: “As for the style of Kyr Andrey's writings, it differs in different works. Larger ascetic works... are characterized by a heavy philosophical style... As for the language, he wrote in Ukrainian language that was spoken in Galicia at the time..."7. By the way, the prominent Ukrainian writer and contemporary of Metropolitan, Ivan Franko drew attention to this: "Bishop, now Metropolitan Andrey Sheptytsky, from the very beginning of his accession to the bishopric began to accustom us to a different tone, other forms, a different character that reigns in his messages. To begin with, he writes his letters in a pure Galician-Rus national language instead of the moldy pseudochurch language, spoken by his predecessors, that is, a mishmash of Church Slavonic vocabulary with modern morphology. And sometimes, for example in A Loud Message to the Hutsuls, he is not shy to speak a dialect - a

\footnotetext{
${ }^{4}$ Базилевич М. Анатоль. Введення у твори митрополита Андрея Шептицького. Праці Українського Богословського Наукового Товариства. Т. XV. Торонто, 1965. С. В 22-231.

${ }^{5}$ Ibid.

${ }^{6}$ Ibid. C. B 232.

${ }^{7}$ Базилевич М. Анатоль. Введення у твори митрополита Андрея Шептицького. Праці Українського Богословського Наукового Товариства. Т. XV. Торонто, 1965. С. В 235-236.
} 
matter, still unheard from our church dignitaries, who considered themselves to be not only masters of souls, but also masters of a language that they considered permissible to mutilate and pervert in their liking... And finally, most importantly, Metropolitan Andrey, without comparison, knows more about life, its real interests and conflicts, than his predecessors, professional theologians and "Roman doctors"... Metr. Andrey talks about things as a European, he thinks and forces to think anyone who wants to talk to him...”. . Sophia Sheptytska - mother of Roman, in her memoirs, and G. Miriam-Luzhnitsky also wrote about the formation of the future Metropolitan?.

In 1991 were published Andrey Sheptytsky's "Letters-epistles", dating the years of the Nazi occupation of Galicia (1939-1944). The most famous of them were the pastoral messages of Metropolitan "Do not kill", "About education", "Propaganda of apostasy", "About the liberal conscience", "In the cause of understanding", "My answers" and more. I. Stefanyuk, the editor of these texts, in his preface drew attention to the evolution of Metropolitan in his pastoral epistles. "The content of the first pastoral epistles of Metropolitan Andrey," the author reasoned, "was mostly a simple catechism. Metropolitan Andrey, as a good teacher of his flock, exchanged the small truths of the holy faith according to the level of his faithful. Compared to the first letters, the last letters of Metropolitan Andrey have a larger theological content... Another reason why we publish this volume of Letters-epistles is that many of the affairs that Metropolitan Andrey wrote about in the forties are still very relevant today. The time when Metropolitan Andrey wrote them is not so far from us: it is separated by one generation..."

The thoughts of Metropolitan in "How to Build a Native Hata" (Message to the Clergy. From the Decrees of the Archbishop Cathedral, 1942) remain relevant: "The ideal of our national life is our native nation-wide MotherlandHata... The task of the Ukrainian people will be to create such socio-Christian circumstances that would assure the citizens of true and sustainable happiness and have sufficient internal strength to counteract the centrifugal tendencies of internal disintegration and successfully protect the borders from external enemies. Such a powerful organization, which is reassuring happiness for all citizens, can be the Motherland only when it is not artificially made up from

${ }^{8}$ Франко I. Соціяльна акція, соціальне питання і соціалізм: Уваги над пастирським посланням митрополита А. Шептицького «О квестії соціяльній». Будівничий української державності: Хрестоматія політологічних статей Івана Франка / Упоряд. Д. Павличко. К.: Вид. дім «Києво-Могилянська академія», 2006. С. 499-500.

9 Шептицька Софія. Молодість і покликання о. Романа Шептицького. Львів: Видавництво «Свічадо», 2015. 292 с.; Дванадцять листів о. Андрея Шептицького до матері / Упор. Г. Меріам-Лужницький. Львів: Світ, 1994. 80 с.

10150 думок Митрополита Андрея Шептицького / Упор. Тереза Ференц. Львів: Свічадо, 2015. 144 с. 
different, heterogeneous parts, but only when it is like a monolith, one organism, that is, a body, animated by one spirit, which develops from the inner vital force, complements the internal connections and is healthy from its nature, strong, conscious of its goals, not only with its material body, but also with its moral body..."11. The Ukrainian hata must be protected if trouble arises. Isn't Ukraine in such a situation today? Interesting parallels between Sheptytsky's ideas and modern time we find in the current research of M. Marynovych: "Is every compromise with the aggressor correct? No! Sheptytsky, at different times and under different circumstances, gave very clear explanations: "Because this is not peace, when someone has to agree to something with someone else's will, and therefore people try to break that agreement and fight - to wage war, because that same agreement is not a peace for them, because it is contrary to the understanding of what they desire" $"$.

In 1995, the editorial board of J. Andriishyn, O. Hayova, L. Husar, A. Kravchuk and O. Matsiuk began publishing the first most complete collection of Metropolitan's works ${ }^{13}$. A. Kravchuk defined the main purpose of this publication this way: "To acquaint the widest range of interested readers with the ecclesiological and ecumenical heritage of Metropolitan Andrey Sheptytsky and to encourage new studies of this complex part of the recent history of the Ukrainian Greek Catholic Church. We hope that this collection will encourage scientific study of this important topic. Considering Metropolitan's multifaceted heritage (more than twenty volumes of material collected through postulation in the canonization case and archival funds), this collection does not claim to be complete. This is just a selection that, with its content and limitations, highlights the present state of such researches. The editorial board tried to lay the

${ }^{11}$ Шептицький А. Як будувати Рідну Хату? Львів: Свічадо, 1999. С. 3-4.

12 Митрополит Андрей Шептицький: Життя і Діяльність. Документи і матеріали. 1899-1944 / Упор. Оксана Гайова, Андрій Кравчук. Т. II. Церква і суспільне питання. Книга 2: листування / За ред. Андрія Кравчука. Львів: Видавництво отців василіан «Місіонер», 1999.С. 970.

${ }_{13}$ Митрополит Андрей Шептицький: Життя і Діяльність. Документи і Матеріали. 1899-1944 / Упор. Оксана Гайова, Андрій Кравчук. Т. II. Церква і суспільне питання. Книга 1. Пастирське вчення та діяльність / За ред. Андрія Кравчука. Львів: Видавництво отців василіан «Місіонер», 1998. 572 с.; Митрополит Андрей Шептицький: Життя і Діяльність. Документи і матеріали. 1899-1944 / Упор. Оксана Гайова, Андрій Кравчук. T. II. Церква і суспільне питання. Книга 2: листування / За ред. Андрія Кравчука. Львів: Видавництво отців василіан «Місіонер», 1999. 571-1096 с.; Митрополит Андрей Шептицький: Життя і Діяльність. Документи і матеріали. 1899-1944 / Упор. Юрій Аввакумов, Оксана Гайова. Т. ІІІ. Митрополит Андрей Шептицький і греко-католики в Росії. Книга 1. Документи і матеріали. 1899-1917. Львів: Видавництво Українського Католицького Університету, 2004. 924 с.; Митрополит Андрей Шептицький: Життя і Діяльність. Церква і Церковна єдність. Документи і матеріали. 1899-1944 / Упор. Андрій Кравчук, Оксана Гайова. Т. 1. Львів: Монастир Монахів Студійського Уставу Видавничий Відділ «Свічадо», 1995. 524 с. 
groundwork for new, still unexplored issues and to shed new light on the findings of the previous researches. If this volume encourages current and future scholars to disseminate and improve the knowledge of the primary sources of our church historiography, and if it raises the level of understanding of the Church's concept and issues of Church unity, we will consider it successful"14.

The first volume, entitled "Church and Church Unity. Documents and Materials. 1899-1944" included pastoral messages, letters and other works by Metropolitan. Although they covered a long period of time, the authors, in our view, managed to group them successfully into separate sections: "From Early Unitarian Activity and Writings on the Church (1899-1913)", "Correspondence with Orthodox Correspondents (1901-1910)" , "Letters from Orthodox who went to the GCC and from those who wish to join (1903-1942)", "The Church Issue in the Time of Military Disasters (1914-1919)", "The Case of the GCC in Eastern Ukraine (1918-1928)", "The Case of the GCC in Belarus, Russia and other territories outside the Lviv Archdiocese (1917-1934)", "From the works and activities of Metropolitan in the Case of Church Unity (1920-1939)", "From the External Relations of the GCC (1921-1943)", "Protection of the Persecuted Orthodox Churches (1929-1930)", "From the Works and Activities of Metropolitan in the Case of the Church and the Unity (1939-1942)", "From the Acts of the Archdiocesan Councils (1940-1943)", "Correspondence with the Orthodox in the Case of Understanding (1941-1943)". The materials end with a selected correspondence of $1941-1944^{15}$. For the first time on the pages of this volume, the editors put the main milestones in the life and activities of the Metropolitan of Halicia ${ }^{16}$. Some fragments of these messages have already been published in other collections of Metropolitan's works ${ }^{17}$.

The second volume, consisting of two books, was called "The Church and the Social Issue". A. Kravchuk, who wrote an introduction, introduced the concept of this publication to the readers. "Into this volume," he wrote, "we tried to include the documents and materials that would cover a key part of Metropolitan Sheptytsky's practical ethics in the first half of the twentieth century, precisely the attitude of the Church to the society and states. The main issue is developing in two planes, or around two groups of issues. The first group concerns the role of the Church in society; how to apply Christian principles to

\footnotetext{
${ }^{14}$ Митрополит Андрей Шептицький: Життя і Діяльність. Церква і Церковна єдність. Документи і матеріали. 1899-1944 / Упор. Андрій Кравчук, Оксана Гайова. Т. 1. Львів: Монастир Монахів Студійського Уставу - Видавничий Відділ «Свічадо», 1995. С. XVIII.

${ }_{15}$ Митрополит Андрей Шептицький: Життя і Діяльність. Церква і Церковна єдність. Документи і матеріали. 1899-1944 / Упор. Андрій Кравчук, Оксана Гайова. Т. 1. Львів: Монастир Монахів Студійського Уставу - Видавничий Відділ «Свічадо», 1995. С. 446-472.

${ }^{16}$ Ibid. C. XXV-XXXII.

${ }^{17}$ Шептицький А. Послання любови. Брустури: Дискурсус, 2015. С. 34.
} 
the life of the human community?; how could the notion of "community" be extended from narrow, clan or ethno-national categories to all-human, universal, Christian categories? Here, incidentally, Metropolitan Sheptytsky contrasts the so-called pagan patriotism, which he rejects, and the Christian patriotism, which he offers to the Ukrainian people. The second group of questions concerns the institutional level of church-state relations...» ${ }^{18}$. Thus, the first part includes the official teachings and pastoral letters of Metropolitan, and the second contains epistolary materials. All the materials, contained in the volume, are divided into three sections: the basics of Christian social life, the appeal to particular communities and groups, and the application of Christian ethics to socio-political reality. A. Kravchuk also emphasizes the three features of Metropolitan's social ethics: 1) close connection with the concept and duty of solidarity; 2) almost prophetic insight into the diagnosis of social reality; 3) its flexibility, openness, dynamism. The scientist draws attention to the need to promote more actively the life and multifaceted activities of A. Sheptytsky. "Today, perhaps," A. Kravchuk states, "the greatest need is the honest presentation of the truth about our church history, without ideological concerns, especially for the eastern regions of Ukraine, where Metropolitan remains insignificant or perceived through the prism of outdated prejudices. The reform of the historiographic assessment of the UGCC is just beginning, and the figure of Metropolitan Andrey is, without any doubt, the central point in this case" ${ }^{\text {"19 }}$. This volume included documents covering the period from August 2, 1899 to November 1943.

The second book of the second volume opens the letter of the famous Ukrainian writer Andriy Tchaikovsky to Metropolitan $^{20}$. In the author's deep conviction, "these letters united a Highly Blessed Rus people, who accepted your nomination, like any fact of general importance, with disbelief. I confess that I was not one of those pessimists, but they were the ones who added Polish intrigue here and everywhere. Your letters should have allayed those doubts and generated sincere sympathy for you. Such patriotic statements of the Bishop in

${ }^{18}$ Митрополит Андрей Шептицький: Життя і Діяльність. Документи і Матеріали. 1899-1944 / Упор. Оксана Гайова, Андрій Кравчук. Т. II. Церква і суспільне питання. Книга 1. Пастирське вчення та діяльність / За ред. Андрія Кравчука. Львів: Видавництво отців василіан «Місіонер», 1998. с. Х.

${ }_{19}$ Митрополит Андрей Шептицький: Життя і Діяльність. Документи і Матеріали. 1899-1944 / Упор. Оксана Гайова, Андрій Кравчук. Т. II. Церква і суспільне питання. Книга 1. Пастирське вчення та діяльність / За ред. Андрія Кравчука. Львів: Видавництво отців василіан «Місіонер», 1998. С. ХХІ.

${ }^{20}$ Митрополит Андрей Шептицький: Життя і Діяльність. Документи і матеріали. 1899-1944 / Упор. Оксана Гайова, Андрій Кравчук. Т. II. Церква і суспільне питання. Книга 2: листування / За ред. Андрія Кравчука. Львів: Видавництво отців василіан «Місіонер», 1999. С. 571-574. 
the pastoral letters reassure and awaken confidence, and this is the basis for understanding and further work... $\rangle^{21}$. To this we should add, that correspondence between Metropolitan and Andriy Tchaikovsky continued for a long time. In 2002, on the initiative of Lviv historian B. Yakymovych, a unique three-volume edition "Andriy Tchaikovsky. Memoirs. Letters. Research" was published"22. It contains all the letters of the writer to Andrey Sheptytsky ${ }^{23}$. A. Sheptytsky is also mentioned in Andriy Tchaikovsky's Autobiography: “...It was not for the first time in our history: not many years before [it - Aut.] in the polonized Earl family of Sheptytsky, the young dragoon officer Roman was appointed as the future head of the Ukrainian Uniate Church, for the purpose of spreading the union throughout Dnieper Ukraine, and further in Russia with his help" ${ }^{24}$. B. Yakymovych wrote that "Memories from Ten Years Ago" is one of the most rare books among all of A. Tchaikovsky's works, because only few copies of it have reached our time. In the book collection of Stepan Kovalyshyn there is a unique copy of a book with a gift inscription to Andrey Sheptytsky: "To the Most Holy Metropolitan Kyr Andrey in the proof of deep devotion. Author» ${ }^{25}$.

As for the letters in the second book of the second volume, "Church and Social Issue", they are all grouped in chronological order according to the issues (1899-1914. A social issue in the Austrian context; 1914-1923. New tasks during and after the World War I; 1917-1929. New tasks in Galicia; 1920-1923. Mission of Metropolitan Andrey Sheptytsky abroad; 1923-1939. Struggling for justice in interwar Poland; 1939-1941. Protecting the Faith against Soviet atheism; 1941-1944. The Sanctity of Life. Resistance to the German occupation power ${ }^{26}$. Here is just a fragment from Metropolitan's speech above the grave of

\footnotetext{
${ }^{21}$ Ibid. C. 572.
}

22 Чайковський Андрій. Спогади. Листи. Дослідження: У 3 т. / Упорядкування Б. 3. Якимовича за участю 3. Т. Грень, О. В. Седляра; Редкол.: Б. З. Якимович (голова) та ін. Львів, 2002. Т. 1. 514 с.; Чайковський Андрій. Спогади. Листи. Дослідження: У 3 т. / Упорядкування Б. 3. Якимовича за участю 3. Т. Грень, О. В. Седляра; Редкол.: Б. 3. Якимович (голова) та ін. Львів, 2002. Т. 2. 468 с.; Чайковський Андрій. Спогади. Листи. Дослідження: У 3 т. / Упорядкування Б. 3. Якимовича за участю 3. Т. Грень, О. В. Седляра; Редкол.: Б. З. Якимович (голова) та ін. Львів, 2002. Т. 3.576 с.

23 Чайковський Андрій. Спогади. Листи. Дослідження: У 3 т. / Упорядкування Б. 3. Якимовича за участю 3. Т. Грень, О. В. Седляра; Редкол.: Б. З. Якимович (голова) та ін. Львів, 2002. Т. 2. С. 24, 123-126; 133-135; 141-142; 162; 183-184; 192; 213; 215-216; 260-262; 281; 289-290; 294-298; 309.

${ }^{24}$ Чайковський Андрій. Спогади. Листи. Дослідження: У 3 т. / Упорядкування Б. 3. Якимовича за участю 3. Т. Грень, О. В. Седляра; Редкол.: Б. З. Якимович (голова) та ін. Львів, 2002. Т. 3. С. 54-55.

${ }^{25}$ Ibid. C. 302.

${ }^{26}$ Митрополит Андрей Шептицький: Життя і Діяльність. Документи і матеріали. 1899-1944 / Упор. Оксана Гайова, Андрій Кравчук. Т. II. Церква і суспільне питання. 
Markian Shashkevych: "We are gathered somewhere by a great powerful idea, and Markian was like its flag. This idea, which was an impulse for our national revival, exists somewhere and it forever will be a stub of living healing water, irrigating the branches of church and folk life, and freshing the greens of hope for the future" ${ }^{27}$. These words can also be confidently said about Metropolitan of Galicia.

Among the correspondents of A. Sheptytsky are Yevhen Olesnytsky, Rafail Krynytsky, Mykhailo Tyshkevych, Hryhoriy Mykytei, Tyt Voynarovsky, Andriy Biletsky, Dmitro Levytsky, Volodymyr Kubijovych and many others. In his letter to Stalin, Metropolitan wrote with pain in his heart: "Propaganda of godlessness in general, and in a special way in schools and among youths, is a great mistake of the Soviet authorities on our territory. First of all, it impresses and terrifies people, who are attached to their faith as the most important part of the folk tradition, and causes that people, especially the masses of the peasantry, do not have....28 [The letter is, probably, incomplete - Aut]. A. Sheptytsky complained to the head of the government of the UkrSSR Khrushchev about the termination of activity of the metrical archive ${ }^{29}$.

In 2003, J. Pelensky published a correspondence of V. Lypynsky, from which we learn many previously unknown facts about the life and activity of Metropolitan of Galicia: “...Andrey Sheptytsky during his visit to Lypynsky on November 5, 1929 bought from him all, except for family letters, correspondence... including about ten thousand letters, which should go to the National Museum in Lviv... The sold letters remained at Lypynsky until the end of his life and could be transferred to the public not earlier than ten years after his death. Later, less than a month before his death, urgently needing money to go to the sanatorium, Lypynsky wrote a letter to Metropolitan (16. V. 1931) and, mentioning an earlier conversation, asked to send him 500 USD. In return, he offered the manuscript of his works, that he had begun, but couldn't finish due to the illness, as well as numerous notes on various socio-political topics. Metropolitan managed to send only part of the needed sum (200 USD), which

Книга 2: листування / За ред. Андрія Кравчука. Львів: Видавництво отців василіан «Місіонер», 1999. С. 571-1028

${ }^{27}$ Митрополит Андрей Шептицький: Життя і Діяльність. Документи і матеріали. 1899-1944 / Упор. Оксана Гайова, Андрій Кравчук. Т. II. Церква і суспільне питання. Книга 2: листування / За ред. Андрія Кравчука. Львів: Видавництво отців василіан «Місіонер», 1999. Митрополит Андрей Шептицький: Життя і Діяльність. Документи і матеріали. 1899-1944 / Упор. Оксана Гайова, Андрій Кравчук. Т. ІІ. Церква і суспільне питання. Книга 2: листування / За ред. Андрія Кравчука. Львів: Видавництво отців василіан «Місіонер», 1999. с. 595.

${ }^{28}$ Ibid. C. 903.

${ }^{29}$ Ibid. C. $905-906$. 
Lypynsky received on May 29, 1931"30. In a letter to the editorial board of the magazine "Theology", V. Lypynsky praised Metropolitan's perennial work: "All the undertakings intended to revive the Ukrainian tradition and the Ukrainian conservatism were met with the active assistance of Count Andrey Sheptytsky

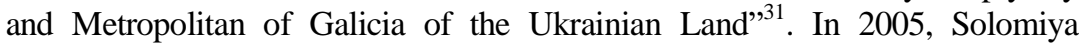
Dyakiv edited and published "Letters from Metropolitan Andrey Sheptytsky to Hilarion Swientsitski”32 - first and long-time director of the National Museum, organizer of the museums in Galicia. This epistolary heritage reveals a great number of topics and a wide range of issues on museum activity, as well as the role of international cultural relations and cooperation between the National Museum in Lviv and a number of European scientific and artistic institutions. The letters were published facsimile. Some of them are handwritten (most are done by the hand of Metropolitan A. Sheptytsky's Secretary), the rest are typed. However, unfortunately there is no comprehensive information about the number of lost letters that have not reached our time. The collection of letters contains interesting and at the same time little-known facts, that have not yet attracted the attention of the researchers, which has led to the lack of their publications, except for individual letters and fragments of them. The letters are presented in chronological order, creating a general perception of them in historical sequence, and covering the period from 1912 to May $1943^{33}$.

In 2004 Y. Avvakumov and O. Hayova edited a large volume of documents and materials entitled "Metropolitan Andrey Sheptytsky and Greek Catholics in Russia", which covered the period from 1899 to 1917. The collection contains documents kept in the Central State Historical Archive of Ukraine in Lviv, and it covers the activities of Metropolitan Andrey in Russia, especially those concerning the Greek Catholic movement among the Russians. The vast majority of documents have not been published before, or have been published incompletely or inaccurately. During this difficult work, which lasted for seven years (1997-2004), 240 documents were selected by the editors, "the vast majority of which are letters from Russian Greek Catholics to Metropolitan Andrey and his letters of reply ${ }^{\text {34 }}$. By the way, out of 240 documents, only

30 Листування В. Липинського / Редактори Я. Пеленський, Р. Залуцький, Х. Пеленська та ін. Т. 1. К.: Смолоскип, 2003. С. 144 («Архів»).

${ }^{31}$ Ibid. C. 218.

32 Листи Митрополита Андрея Шептицького до Іларіона Свєнціцького 3 архіву Національного музею у Львові / Упорядник Соломія Дяків. Львів: Українські технології, 2005. 108 с. + іл.

${ }^{33}$ Ibid. C. 7-8.

${ }^{34}$ Митрополит Андрей Шептицький: Життя і Діяльність. Документи і матеріали. 1899-1944 / Упор. Юрій Аввакумов, Оксана Гайова. Т. III. Митрополит Андрей Шептицький і греко-католики в Росії. Книга 1. Документи і матеріали. 1899-1917. Львів: Видавництво Українського Католицького Університету, 2004. с. XIV. 
55 are Sheptytsky's materials - the rest are letters and memos received by the Galician bishop from different persons. Speaking about the historical context of the documents, J. Avvakumov conditionally identified several problematic nodes that emerge from this epistolary heritage of Metropolitan: 1) Greek Catholics between the Austro-Hungarian Empire and the Russian Empire; 2) the role of the Roman Apostolic See; 3) the situation of the Russian Orthodox Church and religious revival in Russia. The editors drew attention to the fact that drafts of letters for Andrey Sheptytsky were written by the Russians Ivan Deibner, Alexey Zerchaninov, Leonid Fedorov (A. Sheptytsky believed that he did not speak Russian perfectly - Aut.). "The story, told on these pages by the living witnesses of those years," the preface says, "is full of successes and failures, victories and defeats, spiritual quests and hopes that have come true and that are not destined to be fulfilled. With all its complexity and ambiguity, this story touches the very fundamental, pressing and urgent questions of self-awareness and identity of Catholics of the Eastern tradition, to whatever country or nationality they belong. To paraphrase the famous statement of Mykhailo Hrushevsky, let's say that the documents that reader can read will help in the search for answers to the question: "Who are Greek Catholics and what do they want?"35.

Collection of documents "Metropolitan Andrey Sheptytsky and Greek Catholics of Russia" is ended with valuable applications (extracts from Vladimir Solovyov's article "The Slavic Question" (1884); Apostolic Message of Pope Leo XIII on the Preservation and Promotion of Prosperity of the Eastern Churches (1894); Circular Message of Patriarch Joakim III and the Synod of Constantinople Church to all the Orthodox Churches (1902); Memoirs of Father Mykola Tolstoy (1914); Fragments of the discussion on Russian Catholicism on the pages of the magazine "The Word of Truth" (1913-1915) and memoirs of Mykola Trague about his stay in Galicia in 1908-1913 (1915-1916) ${ }^{36}$. In a letter to Russian Orthodox Bishop Antony Khrapovytsky in 1904, Metropolitan Andrey stated ambiguously: "What is there to interpret for a long time about the superiority of one Church over another? It is clear to everyone. There is only one true Church of Christ in the world: whether it is Orthodox, as you call it, or Catholic, as we call it. It is now split in half. But it was not divided by itself, it

35 Митрополит Андрей Шептицький: Життя і Діяльність. Документи і матеріали. 1899-1944 / Упор. Юрій Аввакумов, Оксана Гайова. Т. III. Митрополит Андрей Шептицький і греко-католики в Росії. Книга 1. Документи і матеріали. 1899-1917. Львів: Видавництво Українського Католицького Університету, 2004. с. XLIX.

${ }_{36}$ Митрополит Андрей Шептицький: Життя і Діяльність. Документи і матеріали. 1899-1944 / Упор. Юрій Аввакумов, Оксана Гайова. Т. III. Митрополит Андрей Шептицький і греко-католики в Росії. Книга 1. Документи і матеріали. 1899-1917. Львів: Видавництво Українського Католицького Університету, 2004. С. 745-857. 
was forcibly divided by politics. Therefore, it must be reunited, it must do it certainly, it must do it necessarily, it must do it for Christ sake, for the sake of true God! All noble souls, whether among Catholics or Orthodox, feel this need"37. Metropolitan Andrey has never changed this firm position.

During 2007-2013 Metropolitan Andrey Sheptytsky's most complete fourvolume edition of the "Pastoral Epistles" was published ${ }^{38}$. Well-known Ukrainian archivists Oksana Hayova and Roman Terekhovsky were its editors. In his introduction to the first volume, B. Dziurakh rightly noted that "hundreds and thousands of pages can be written about Metropolitan. You can analyze one or another aspect of his teachings or give a general description of his work. Yet, nothing, even the best comments and analyzes, will change the happiness of personal immersion into the word of the Good Shepherd of the Ukrainian land, when a person has the opportunity to discover the "treasure hidden in the arable land" of church history, and to directly share in the wisdom and the strength of spirit that live in the words of Kyr Andrey" ${ }^{\prime 39}$. The first volume of this fundamental edition includes the pastoral epistles of Metropolitan from 1899 to 1914. In the end of the publication there is an extraordinarily original work by Bishop J. Botsian "Pastoral Letters of Metropolitan Andrey (Literary Review)", published in $1925^{40}$. The author, conditionally dividing Sheptytsky's pastoral heritage into two stages - the bishop's and the metropolitan's, summed up: "Regarding the form, the letters themselves repeatedly mention that they were written fast, in the midst of a great lack of time... More valuable, however, than the style and the garments of the word is the heart that lurks beneath them - its warm love, gentleness and noble tact, even in those cases where it is necessary to say a bold word..."41. The first volume included 52 documents, the last of which dates from September 6, 1914, when Russian tsarist troops were coming closer to Lviv. Metropolitan states with sadness: "Awful destruction is all around us,

${ }^{37}$ Ibid. C. 92-93.

${ }^{38}$ Шептицький Андрей. Пастирські послання 1899-1914 pp. Т. І / Упорядники: Оксана Гайова, Роман Тереховський. Львів: Фундація «Андрей»; Видавничий відділ «Артос», 2007. L+1014 с.; Шептицький Андрей. Пастирські послання 1918-1939 pp. Т. II / Упорядники: Оксана Гайова, Роман Тереховський. Львів: Фундація «Андрей»; Видавничий відділ «Артос», 2009. ХІІ+1014 с.; Шептицький Андрей. Пастирські послання 1939-1944 pp. Т. III / Упорядники: Оксана Гайова, Роман Тереховський. Львів: Фундація «Андрей»; Видавничий відділ «Артос», 2010. XXXII+828 с.; Шептицький Андрей. Пастирські послання. Спільні пастирські послання. T. IV / Упорядники: Оксана Гайова, Роман Тереховський. Львів: Фундація «Андрей»; Видавничий відділ «Артос», 2013. XIV+1194 c.

${ }^{39}$ Шептицький Андрей. Пастирські послання 1899-1914 pp. Т. I / Упорядники: Оксана Гайова, Роман Тереховський. Львів: Фундація «Андрей»; Видавничий відділ «Артос», 2007. C. XLIX.

${ }^{40}$ Ibid. C. $857-912$.

${ }^{41}$ Ibid. C. 912. 
the whole villages are destroyed, some have disappeared from the face of the earth. Homes burned, property ruined, thousands of families destroyed. Many families have fled from scare: relatives do not know where the children went. The people in abandonment left their native home. We have lost many of ours..., ${ }^{, 2}$. Ukraine was entering an extremely difficult and at the same time a heroic period of its history...

The second volume of pastoral messages covers the interwar period of the Ukrainian history (1918-1939). World War I ended, the Western Ukrainian People's Republic emerged, Eastern Galicia was part of Poland for twenty years, undergoing the sanctions regime, and in 1939 it was occupied by the Soviet troops, who, according to the Molotov-Ribbentrop Pact, divided Europe. These are just the most significant events that radically changed the geopolitical situation before World War II. All this time Metropolitan remained the true spiritual leader of his people. The volume included 72 documents, that is, pastoral messages, as well as scientific works on the topic of church unity, "The Mission of Monasticism in the Unification of the Churches" (1921), "The Role of the West in the Unification of the Churches" (1923), "The Restoration of Slavic Monasticism" (1923), "The Psychology of the Union" (1925) and "The Two Mentalities" (1926). The collection is ended with the works of Metropolitan on moral and pastoral topics.

The third volume of Andrey Sheptytsky's pastoral epistles concerns the period of 1939-1944, when German Nazism replaced Bolshevik's occupation of Galicia, and later it was followed by the "second coming" of the Bolsheviks. "The card of history has turned, a new epoch has come"43 - in such words Metropolitan Andrey begins his pastoral message on September 26, 1939. M. Marynovych, who wrote the preface to this volume, rightly noted: "That this danger was really terrible, everyone could be convinced immediately after the entry of the Red Army into Lviv. However, many Galicians meet the Soviet troops with curiosity and hope. After all, the Polish authorities, whose ethnic minority policies were more unforgiving and who punished mercilessly for any attempt at seclusion, came to an end. So, in this sense, release seems to have come for Ukrainians. The tragic division of the people ended, and the dreamy "golden-haired Kyiv" became close and accessible again. Not one at the time thought to himself: "Maybe all these rumors of the horrors of the Bolshevik regime were fictions? Maybe it was all hostile propaganda, and the Soviets really care for the ordinary people?" But further reality turned out to be more terrible

\footnotetext{
${ }^{42}$ Ibid. C. 829.

43 Шептицький Андрей. Пастирські послання 1939-1944 pp. Т. III / Упорядники: Оксана Гайова, Роман Тереховський. Львів: Фундація «Андрей»; Видавничий відділ «Артос», 2010. С. 7.
} 
than any rumors" 4 . Mass repressions, persecution of the clergy and ordinary people, the politics of silence have become an ordinary thing. And all this continued until the entry of German troops into Galicia. Metropolitan was optimistic for a new government that would allow Ukrainians to live a state life. "From the will of Almighty God, in the Trinity of the One, a new era began in the life of the State United Independent Ukraine" ${ }^{, 45}$. Sheptytsky calls on Ukrainians for unity: "All those who feel themselves Ukrainians and who want to work for the good of Ukraine, let them forget about any party strife, let them work in unity and consent to restoring our economic and cultural life, destroyed so much by the Bolsheviks" ${ }^{46}$. Very soon Metropolitan will be convinced that the Stalinist USSR and Hitler's Nazism are "twin brothers" that are not significantly different from each other. We must agree with M. Marynovych's claim that 1942 could be considered crucial for Metropolitan in his condemnation of Nazi ideology ${ }^{47}$. "This system of untruth, deceit, injustice, robbery, caricatures of all ideas of civilization and order," A. Sheptytsky writes in a letter to Pope Pius XII. "This system of excessive selfishness on an absurd level, completely crazy national chauvinism, hatred of all that is honest and good, this system is something so phenomenal that stupor is perhaps the very first feeling the one has got when he sees this monster. Where does this system lead the unfortunate German nation? Only to such a degeneration of race, which the history of mankind has never seen" ${ }^{\text {"48 }}$. Metropolitan also did not expect anything comforting from the new arrival of the Bolsheviks: "Our Church will be destroyed, ruined by the Bolsheviks. But hold on..."49.

The fourth volume of the pastoral messages of A. Sheptytsky included common pastoral messages covering the period from 1905 to 1943, as well as selected works - "Catechism", "Memoir from Zarvanytsia", "Spiritual Exercises", "God's Sowing", "From the history and problems of our thing (art - Aut.)", "Sciences and spiritual apprehension...", «General principles of moral theology", "Russian Catholic Exarchate", "My memories of the

\footnotetext{
${ }^{44}$ Ibid. C. XI.

${ }^{45}$ Ibid. C. 114.

46 Шептицький Андрей. Пастирські послання 1939-1944 рр. Т. III / Упорядники: Оксана Гайова, Роман Тереховський. Львів: Фундація «Андрей»; Видавничий відділ «Артос», 2010. С. 116.

${ }^{47}$ Ibid. C. XXVIII.

${ }^{48}$ Митрополит Андрей Шептицький: Життя і Діяльність. Церква і Церковна єдність. Документи і матеріали. 1899-1944 / Упор. Андрій Кравчук, Оксана Гайова. Т. 1. Львів: Монастир Монахів Студійського Уставу - Видавничий Відділ «Свічадо», 1995. С. 985.

${ }^{49}$ Ibid.
} 
subject of museum collections", etc ${ }^{50}$. The volume is ended with the "Sermons" (1937-1943) $)^{51}$.

Although he has repeatedly stated that the church should be out of politics, Metropolitan Andrey Sheptytsky was quite active in it. With enormous authority among the people, he could not but respond to the political situation in the country, which in the first half of the twentieth century was changing all the time. This is easy to see when reviewing a number of collections of documents pertaining to the national liberation movement in Eastern Galicia (1918-1922), the interwar period in the history of the region, World War II (1939-1944), the preparation and liquidation of Catholic Church in Western Ukraine by the Soviet authorities ${ }^{52}$. It is documented that on June 29, 1941, the battalion, headed by R. Shukhevych, was the first to enter Lviv, ahead of the Germans for several hours. At half past seven, that morning, Metropolitan had already received a Kurin delegation led by sotnyk Shukhevych, after which he blessed nationalist soldiers lining up at his residence ${ }^{53}$. I. Kindrat recalled that on June 29, 1941, he "found himself in the group of 28 defenders of Metropolitan and his residence at St. George's Cathedral. After barricading ourselves in the church and the residence, we waited... It is plausible that the NKVD did not have the time or the courage to attack us, and so everything ended without a confrontation between us"

${ }^{50}$ Шептицький Андрей. Пастирські послання. Спільні пастирські послання. T. IV / Упорядники: Оксана Гайова, Роман Тереховський. Львів: Фундація «Андрей»; Видавничий відділ «Артос», 2013. С. 257-958.

${ }^{51}$ Ibid. C. 959-1018.

52 Західно-Українська Народна Республіка. 1918-1923. Документи і матеріали. Т. 1: Листопадова 1918 р. національно-демократична революція. Проголошення ЗУНР / Укладачі: Олександр Карпенко, Катерина Мицан. Івано-Франківськ: Лілея-НВ, 2001. 684 с.; ЗахідноУкраїнська Народна Республіка. 1918-1923. Документи і матеріали. Т. 2: Державотворчі й адміністративно-організаційні процеси / Укладачі: Олександр Карпенко, Катерина Мицан. Івано-Франківськ: Лілея-НВ, 2001. 712 с.; Культурне життя в Україні. Західні землі. Документи і матеріали. Т. 1. 1939-1953. К.: Наукова думка, 1995. 748 с.; Ліквідація УГКЦ (1939-1946). Документи радянських органів безпеки / Упор. Сергій Кокін, Наталія Сердюк, Станіслав Сердюк; за заг. ред. Володимира Сергійчука. Т. І. К. ПП Сергійчук М. І., 2006. 920 с.; Ліквідація УГКЦ (1939-1946). Документи радянських органів безпеки / Упор. Сергій Кокін, Наталія Сердюк, Станіслав Сердюк; за заг. ред. Володимира Сергійчука. Т. II. К. ППП Сергійчук М. І., 2006. 804 с.; Літопис нескореної України: Документи, матеріали, спогади. Книга 1 (Підготували Я. Лялька, П. Максимук, І. Патер та ін.). Авт. передмови Я. Лялька, Р. Бачинський. Львів: Просвіта, 1993. 800 с.+ іл.

${ }_{53}$ Роман Шухевич у документах радянських органів державної безпеки (1940-1950) / За заг. ред. В. Сергійчука. Т. 1. К.: ПП Сергійчук М. І., 2007. С. 7.

54 Літопис нескореної України: Документи, матеріали, спогади. Книга 1 (Підготували Я. Лялька, П. Максимук, І. Патер та ін.). Авт. передмови Я. Лялька, Р. Бачинський. Львів: Просвіта, 1993. С. 375. 
Interesting facts about the activity of A. Sheptytsky during World War II can be found in the four-volume document "Ukraine in the Second World War", prepared for printing by V. Kosyk. The pages of this publication contain the "OUN-Bandera response to the Germans' demand to withdraw the proclamation of the statehood on June 30, 1941", which states unequivocally: "The government [of J. Stetsko - Aut.] has the support of such authorities as Metropolitan of the Uniate Church, Count Sheptytsky"55. The Document "Further Information on the OUN-Bandera and the Murder of Sciborsky and Senyk" provides information about the split that took place at OUN and Metropolitan's attitude towards this ${ }^{56}$. According to the German SD, A. Sheptytsky wrote in a letter to Colonel Andriy Melnyk: "The whole Ukrainian public requires as a necessary prerequisite your mutual agreement with Bandera and the termination of this dispute, so terrible and harmful to the Ukrainian case. It is unthinkable that after the Bolshevik rule, the OUN can bring us a fratricidal war with all the misfortunes that come with it"57. German special services have launched an investigation to authenticate the letter.

On January 14, 1942 A. Sheptytsky, M. Velychkivsky, A. Livytsky, M. Omelyanovych-Pavlenko and A. Melnyk wrote in a letter to Hitler: “...In the Ukrainian central regions, the possibility of cultural and national development is being withdrawn from the Ukrainians, while the difficulties are created for the political press, traditional cultural and educational associations are forbidden, schools are closed, permission for the activity of scientific institutions is withdrawn and professors are unemployed, the nation's brain remains without the possibility of scientific activity, even without the means of livelihood. Such a state of affairs provokes a great discontent in the Ukrainian public about the future of national culture... Unfortunately, today's reality does not give Ukrainians this confidence. Therefore, there is great concern and fear for the future of the nation among the masses and in the ruling circles. The current state of affairs contradicts the historical tasks of Ukraine, which derive from its geographical position..." ${ }^{58}$. By the way, the Soviet security agencies also closely followed

55 Україна в Другій світовій війні у документах. Збірник німецьких архівних матеріалів. Т. 1 / Упорядкування і передмова Володимира Косика. Львів: Інститут українознавства ім. І. Крипякевича НАН України, 1997. С. 214.

56 Україна в Другій світовій війні у документах. Збірник німецьких архівних матеріалів. Т. 1 / Упорядкування і передмова Володимира Косика. Львів: Інститут українознавства ім. І. Крипякевича НАН України, 1997. С. 283-285

${ }^{57}$ Ibid. C. 362-363.

58 Україна в Другій світовій війні у документах. Збірник німецьких архівних матеріалів (1941-1942). Т. 2 / Упорядкування Володимира Косика. Львів: Інститут українознавства ім. І. Крипякевича; Львівський державний університет ім. І. Франка; 
the activities of Metropolitan during the war. There are many reports about this on the pages of the collection of documents "Roman Shukhevych in the Documents of the Soviet State Security Authorities (1940-1950)". People's Commissar of State Security of the USSR V. Merkulov reported that "in the formation of the SS-Halychyna Division and the Military Committee an active role was played by... the representatives of the Uniate Church, headed by Metropolitan Andrey Sheptytsky, personally associated with Melnyk ${ }^{59}$. Another report referred to Metropolitan's support for the Act of June 30, $1941^{60}$.

A huge factual material is contained in the two-volume edition of the documents "Liquidation of the UGCC (1936-1946). Documents of the Soviet State Security Authorities". A researcher of the State Archives of the Security Service of Ukraine N. Serdiuk, analyzing the directive of the UkrSSR KGB "On the Agential Work on the Line of the Greek Catholic Uniate Church, headed by Metropolitan Andrey Sheptytsky", stated: “...the Vatican's agents in the USSR, by underground methods, disseminate Catholicism and, as appropriate, carry out espionage work for the benefit of various foreign powers, and Metropolitan Sheptytsky is involved"61. In general, A. Sheptytsky is mentioned in the vast majority of documents ${ }^{62}$. In the preface to the second volume of this edition, which deals with the liquidation of the UGCC, V. Serhiychuk states: "The offered documents testify to the following: the representatives of the Soviet special services managed to warm up the personal ambitions of Kostelnyk [H. Kostelnyk - a former supporter of A. Sheptytsky, who betrayed his ideas and faithfully served the invaders - Aut.] so much, ambitions, concerning his "messianism" in converting the Uniates to Russian Orthodoxy, that he had already dreamed of creating a special Orthodox Church in Western Ukraine under his leadership. Therefore, he wanted to influence the secret scenario of the elimination of the UGCC, by requiring the representatives of the Bolshevik authorities to take firm repression against the clergy"63. The OUN could not help but respond to it: "Ukrainians are Greek Catholics! Can we,

Інститут української археографії та джерелознавства ім. М. Грушевського НАН України, 1998. C. 86-87.

${ }_{59}$ Роман Шухевич у документах радянських органів державної безпеки (1940-1950) /

За заг. ред. В. Сергійчука. Т. 1. К.: ПП Сергійчук М. І., 2007. С. 352-353.

${ }^{60}$ Ibid. C. 356.

61 Ліквідація УГКЦ (1939-1946). Документи радянських органів безпеки / Упор. Сергій Кокін, Наталія Сердюк, Станіслав Сердюк; за заг. ред. Володимира Сергійчука. Т. І. К. ПП Сергійчук М. І., 2006. С. 16.

${ }^{62}$ Ibid. 65-68, 72-75, 77-80, 82-84, 86-92, 94-96, 9, 100, 103, 105-107, 113, 114, 121, 123 , $125,133-135,138,139,144$ and so on.

${ }^{63}$ Ibid. C. 5. 
therefore, calmly look when enemy, with the help of several broken units from the Greek Catholic clergy, who have embarked on the path of betrayal, is dragging the whole Greek Catholic Church into the abyss? Should we let some timid clergy open the door to our villages and towns for the NKVD fathers? Do we have to wait for our parents, children and relatives to be confessed to informants and the NKVD workers? No!",64.

Therefore, in the twentieth century, one of the most prominent figures of Ukrainian history was undoubtedly Metropolitan of Galicia Andrey Sheptytsky. A prominent religious figure of that time, he played a significant role in the growth of self-awareness of the Ukrainian people. It is difficult to overestimate Metropolitan's contribution to education, science, cultural progress of the Ukrainians. Despite the fact that his activity was spread primarily in Western Ukraine, however, it made a huge resonance with the rest of Ukrainian lands. On this basis, the attention of researchers has always been drawn to this great figure. Even during his lifetime Metropolitan's pastoral messages, memorandums and scientific works were published. Unfortunately, the two world wars, the occupation of Galicia by the Soviet and Nazi troops, the establishment of the communist dictatorship in the land, led to the loss of many works of Metropolitan. Today a fruitful process is underway to return from forgetting the great cultural heritage of Andrey Sheptytsky. In the West, it started earlier, in Ukraine - after proclamation of independence. Nowadays Ukrainian archivists have published several multivolume publications of pastoral messages, letters, memorandums, decrees, historical and theological works. Much work has been done in the direction of the publication of the once banned and now open archives of the Soviet state security agencies. We learned more about the Great Metropolitan - a religious, cultural and political figure, who wanted to see Ukraine as a free and independent state.

64 Ліквідація УГКЦ (1939-1946). Документи радянських органів безпеки / Упор. Сергій Кокін, Наталія Сердюк, Станіслав Сердюк; за заг. ред. Володимира Сергійчука. T. І. К. ПП Сергійчук М. І., 2006. С. 64. 